\title{
Safety and efficacy of levetiracetam for the treatment of partial onset seizures in children from one month of age
}

This article was published in the following Dove Press journal:

Neuropsychiatric Disease and Treatment

20 February 2013

Number of times this article has been viewed

\author{
Justine Cormier \\ Catherine J Chu \\ Massachusetts General Hospital, \\ Department of Neurology, \\ Programs in Child Neurology and \\ Neurophysiology, Boston, MA, USA
}

Correspondence: Catherine J Chu

175 Cambridge Street, Suite 340, Boston, MA 021।4, USA

Tel +l 6177266540

Email cchu3@partners.org

\begin{abstract}
Epilepsy is a common neurological disorder in the pediatric population, affecting up to one percent of children, and for which the mainstay of treatment is anticonvulsant medication. Despite the frequent use of anticonvulsant drugs, remarkably little is known about the safety and efficacy of most of these medications in the pediatric epilepsy population. Of 34 anticonvulsants currently approved for use by the US Food and Drug Administration (FDA), only 13 have been approved for use in children. Although infants and young children are disproportionately affected by epilepsy, there are currently only three anticonvulsant medications that have been specifically evaluated and approved for use in children younger than 2 years of age. In 2012, the FDA approved levetiracetam as an adjunctive treatment for partial onset seizures in infants and children from one month of age. Here we review the available data on levetiracetam in the pediatric epilepsy population. We first discuss the pharmacological profile of levetiracetam, including its mechanism of action, formulations and dosing, and pharmacokinetics in children. We then review the available efficacy, safety, and tolerability data in children from one month of age with partial onset seizures. We conclude that the current data leading to the approval of levetiracetam for use in infants and children with partial onset seizures is encouraging, although more work needs to be done before definitive conclusions can be drawn about the efficacy of levetiracetam across different pediatric age groups.
\end{abstract}

Keywords: levetiracetam, anticonvulsant drug, partial seizures, pediatric epilepsy

\section{Background}

Epilepsy is a common neurological disorder in the pediatric population, affecting up to one percent of children, ${ }^{1,2}$ for whom the mainstay of treatment is anticonvulsant medication. Despite the frequent use of anticonvulsant drugs, remarkably little is known about the safety and efficacy of most of these medications in the pediatric epilepsy population. Of 34 anticonvulsants currently approved for use by the US Food and Drug Administration (FDA), only 13 have been approved for use in children. Identifying safe and effective options for the youngest of these children is even more challenging. Although infants and young children are disproportionately affected by epilepsy, there are currently only three anticonvulsant medications that have been specifically evaluated and approved for use in children younger than 2 years of age. Here we discuss the most recent addition, levetiracetam, a popular anticonvulsant drug increasingly used in pediatric populations to treat seizures associated with a wide range of epilepsy syndromes. ${ }^{3-11}$

Levetiracetam (Keppra ${ }^{\circledR}$, UCB Pharma SA, Brussels, Belgium, Figure 1) is a second-generation anticonvulsant drug that has been available in the US since 1999 


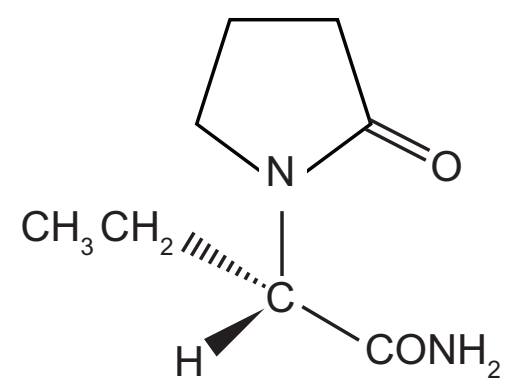

Figure I Levetiracetam chemical structure.

when it was approved by the FDA for adjunctive treatment of partial onset seizures in adults with epilepsy. Levetiracetam has been subsequently evaluated in the pediatric population, gaining FDA approval in 2004 for adjunctive therapy in children from 4 years of age with partial onset seizures, and most recently, in 2012, as adjunctive therapy for partial onset seizures in adults and children one month of age and older with epilepsy. Here we review the available data on levetiracetam in the pediatric epilepsy population. We first discuss the pharmacological profile of levetiracetam, including its mechanism of action, formulations and dosing, and its pharmacokinetics in children. We then review the available efficacy, safety, and tolerability data in children from one month of age with partial onset seizures.

\section{Mechanism of action}

Early studies in rodent models of epilepsy revealed that levetiracetam ((S)- $\alpha$-ethyl-2-oxo-1-pyrrolidine acetamide) acts via a mechanism which is different from that of all prior anticonvulsants. In 2004, synaptic vesicle protein $2 \mathrm{~A}$ (SV2A), a transmembrane protein known to be involved in calcium-dependent exocytosis of synaptic vesicles, was identified as the binding site for levetiracetam. ${ }^{12}$ The affinity of levetiracetam derivatives for SV2A has been strongly correlated with their antiseizure potency in an audiogenic mouse model of epilepsy, ${ }^{12}$ and SV2A-deficient animals show a reduced response to levetiracetam. ${ }^{13}$ While the exact role of SV2A in epilepsy remains unknown, SV2A knockout mice exhibit decreased action potential-dependent GABAergic neurotransmission and severe seizures as they mature. ${ }^{14}$ Autopsy studies in human patients with temporal lobe epilepsy have shown reduced expression of SV2A, ${ }^{15}$ although the etiology and impact of these changes in SV2A expression are uncertain.

\section{Formulations}

Levetiracetam is available as $250 \mathrm{mg}, 500 \mathrm{mg}, 750 \mathrm{mg}$, and $1000 \mathrm{mg}$ tablets, an extended-release formulation,
$100 \mathrm{mg} / \mathrm{mL}$ grape-flavored oral solution, and an intravenous formulation. The broad range of options greatly facilitates dosing and administration to infants and children.

Recommended dosing and titration schedules for children vary somewhat by age, ranging from a target daily dose of $21 \mathrm{mg} / \mathrm{kg}$ twice daily for children under 6 months of age to $30 \mathrm{mg} / \mathrm{kg}$ twice daily for children up to 16 years. Intravenous levetiracetam $(100 \mathrm{mg} / \mathrm{mL})$ has been approved by the FDA for use in partial onset seizures in adult patients ( $>16$ years) with a 1:1 conversion ratio, but is not currently approved by the FDA for use in infants and young children. Two small retrospective studies $\left(n=10^{16}\right.$ and $\left.n=15^{17}\right)$ in infants and children aged from 3 weeks to ten years reported intravenous levetiracetam to be safe and well tolerated at doses in the range of $30-50 \mathrm{mg} / \mathrm{kg} /$ day.

Efficacy in reported clinical trials has been achieved over a wide range of doses. Two prospective addon trials of levetiracetam that have titrated dose to efficacy have found that patients achieving a greater than $50 \%$ reduction in seizure frequency are on mean doses of $30-40 \mathrm{mg} / \mathrm{kg} /$ day (age 6 months to 16 years, $\mathrm{n}=53$ and $\mathrm{n}=31$ ). ${ }^{3,18}$ However, other work has shown that higher doses (70-275 mg/kg/day, median $146 \mathrm{mg} / \mathrm{kg} /$ day) may be efficacious in patients who respond partially to lower doses $(n=32) .{ }^{19}$ The only pediatric epilepsy study to examine plasma concentration showed no linear correlation between efficacy and plasma concentration in 37 patients aged $2-18$ years, although $60 \%$ of responders had a plasma levetiracetam concentration of $5-40 \mu \mathrm{g} / \mathrm{mL}$, and no child responded at lower levels. ${ }^{20}$

\section{Pharmacokinetics}

In adult studies, levetiracetam demonstrated a favorable pharmacokinetic profile characterized by rapid absorption, linear pharmacokinetics, rapid achievement of steadystate dose, and absolute oral bioavailability of $>95 \% .{ }^{21}$ Levetiracetam is minimally metabolized via hydrolysis in the blood, with $66 \%$ of the dose excreted unchanged and $24 \%$ excreted as an inactive metabolite. ${ }^{22}$

Pharmacokinetic studies in children with partial onset seizures have largely shown similar results, but with faster rates of elimination compared with adults, and peaking after infancy. The time to peak plasma concentration in children aged 4-12 years (mean $\mathrm{t}_{\text {max }} 1.4-2.3$ hours) ${ }^{22,23}$ is comparable with that reported in adults (mean $t_{\max } 1.3$ hours), ${ }^{21}$ but the elimination half-life has been observed to be shorter at 5-6 hours ${ }^{22-24}$ compared with $6-8$ hours in adults. ${ }^{21}$ Levetiracetam is excreted renally at rates up to $40 \%$ higher in children aged 2 months to 12 years than in adults, ${ }^{22-24}$ 
although children under 6 months of age have a slightly lower clearance of levetiracetam $(1.23 \mathrm{~mL} / \mathrm{min} / \mathrm{kg}$ versus $1.57 \mathrm{~mL} / \mathrm{min} / \mathrm{kg}$ ) than children older than 6 months. ${ }^{23}$

\section{Drug interactions}

Because levetiracetam is less than $10 \%$ protein bound in plasma $^{22}$ and not dependent on liver cytochrome P450 enzymes for its metabolism, significant drug interactions with levetiracetam are not expected. In vitro pharmacokinetic studies found that levetiracetam does not cause drug interactions when coadministered with drugs metabolized via the cytochrome P450 system. ${ }^{25}$ However, similar to work in adults, ${ }^{26,27}$ there is some evidence to suggest that clearance of levetiracetam in children may be increased by as much as $30 \%$ when coadministered with enzyme inducers. ${ }^{24,28}$ Two studies evaluating drug-drug interactions in children aged 0-17 years found no effect of levetiracetam on plasma concentrations of carbamazepine, valproic acid, topiramate, lamotrigine $(\mathrm{n}=187),{ }^{29}$ or clonazepam $(\mathrm{n}=103),{ }^{28}$ although children younger than 4 years of age were excluded in one study $^{29}$ and infants were not analyzed separately in the other. $^{28}$

\section{Efficacy as adjunctive therapy}

To date, there have been three large, randomized, doubleblind, placebo-controlled trials of levetiracetam as adjunctive therapy for partial seizures in children. Trials ranged from 5 days to 14 weeks in length and showed levetiracetam to be effective and well tolerated for the treatment of partial seizures in infants and children aged from one month to 16 years (age $4-16$ years, $n=198 ;{ }^{6}$ age one month to 4 years, $n=116 ;{ }^{10}$ age $4-16$ years, $n=98^{30}$ ). Efficacy ranged from $43 \%{ }^{6,10}$ to $62 \%^{30}$ of patients achieving $\geq 50 \%$ seizure reduction (versus $20 \%{ }^{6,10}$ to $40 \%{ }^{30}$ with placebo) and from $7 \%{ }^{6}$ to $47 \%{ }^{30}$ achieving seizure freedom (Table 1 ). Only one study evaluated young children (aged one month to 4 years) specifically, and efficacy rates were comparable with other age groups. ${ }^{10}$ Two of these trials were followed by 48 -week open-label trials, which continued to show similar response rates over a longer term $\left(n=152^{31}\right.$ and $\left.n=103^{11}\right)$. In all trials, doses ranged from 20 to $60 \mathrm{mg} / \mathrm{kg} /$ day and were flexible in the open-label extensions, often dosing to efficacy. A 2012 update to the Cochrane Review of adjunctive levetiracetam for partial seizures included two of the randomized controlled trials mentioned above $\mathrm{e}^{6,30,32}$ and concluded that, at the standard dose of $60 \mathrm{mg} / \mathrm{kg} /$ day, levetiracetam is 0.9 times more effective than placebo at controlling partial seizures in children aged $4-16$ years. ${ }^{33}$
Several other prospective and retrospective, open-label, uncontrolled studies of adjunctive levetiracetam for partial seizures in children aged from 6 months to 16 years have largely shown similar results (Table 1), ${ }^{3,5,9,18,34-36}$ with only one study showing as low as $26.1 \%$ of subjects responding (age $0-18$ years, $n=134)^{4}$ and another showing as high as $72 \%$ responding (age $0-10$ years, $n=11$ ) ${ }^{37}$ Of the five studies enrolling both children with partial seizures and children with generalized seizures, levetiracetam was found to be more effective as adjunctive therapy for partial seizures than for generalized seizures in all cases, ${ }^{4,9,18,37,38}$ although only two of these studies demonstrated a significant difference in treatment efficacy according to seizure type., ${ }^{4,9}$

Few studies have directly compared the efficacy of levetiracetam with that of other anticonvulsant drugs. In the absence of definitive data, indirect comparisons across trials may be informative. In 2004, a joint committee from the American Academy of Neurology and American Epilepsy Society published data comparing efficacy across four separate randomized controlled trials of gabapentin, lamotrigine, topiramate, and oxcarbazepine. ${ }^{39}$ While data from randomized controlled trials of levetiracetam in children were unavailable at the time, Verdru et al ${ }^{40}$ later adapted these results to include data on levetiracetam from Glauser et al. ${ }^{6}$ These analyses conclude that, while more effective than gabapentin, levetiracetam exhibits an efficacy and tolerability profile comparable with that of lamotrigine, topiramate, and oxcarbazepine in children up to 16 years of age with partial epilepsy.

\section{Efficacy of intravenous formulation}

The above studies specifically evaluated oral formulations of levetiracetam. Limited data are available evaluating the efficacy of intravenous levetiracetam in children. Cilio et $\mathrm{al}^{41}$ report two cases of migrating partial seizures of infancy; each infant presented in status epilepticus refractory to a number of anticonvulsant drugs, including benzodiazepines. Both patients remained on intravenous anticonvulsant infusions for several months before intravenous levetiracetam was given, and in each case, status epilepticus was terminated within 12 hours of intravenous administration of levetiracetam. ${ }^{41}$ A second retrospective case series in children with complex partial seizures (aged 2 months to 18 years) reported that all 30 patients who received intravenous levetiracetam for either acute repetitive seizures (defined as episodes of at least 30 minutes of repeated seizures, each lasting under 5 minutes, with return to consciousness between each seizure) or status epilepticus all responded clinically and electrographically. ${ }^{42}$ 
Table I Studies of levetiracetam in infants and children with partial onset seizures

\begin{tabular}{|c|c|c|c|c|c|c|c|}
\hline Study & Trial design & Diagnosis & Ages & POS/total \#* & $\begin{array}{l}\text { Duration } \\
\text { (mean) }\end{array}$ & $\begin{array}{l}\text { Dosage } \\
(\mathrm{mg} / \mathrm{kg} / \mathrm{d})\end{array}$ & Efficacy*** \\
\hline $\begin{array}{l}\text { Glauser } \\
2002^{34}\end{array}$ & $\begin{array}{l}\text { Open-label, } \\
\text { prospective, } \\
\text { add-on }\end{array}$ & POS & $6-12 \mathrm{yr}$ & $24 / 24$ & $\begin{array}{l}6 w \text { titrate, } \\
8 w \text { eval }\end{array}$ & $20-40$ & $\begin{array}{l}\text { Sz free: } 2(9 \%) \\
\geq 50 \% \text { red: } 12(52 \%) \\
\geq 75 \% \text { red: } 5(22 \%)\end{array}$ \\
\hline $\begin{array}{l}\text { Wheless } \\
2002^{38}\end{array}$ & $\begin{array}{l}\text { Open-label, } \\
\text { prospective, add-on }\end{array}$ & RE & $6 \mathrm{mo}-14 \mathrm{yr}$ & $25 / 39 * *$ & $\begin{array}{l}\leq 9 \mathrm{mo} \\
(5 \mathrm{mo})\end{array}$ & 45.7 (mean) & $\begin{array}{l}\text { Sz free: } 8 \% \\
\geq 50 \% \text { red: } 33 \%\end{array}$ \\
\hline $\begin{array}{l}\text { Tan } \\
2004^{37}\end{array}$ & $\begin{array}{l}\text { Retrospective, } \\
\text { add-on }\end{array}$ & $\mathrm{RE}$ & $<10 \mathrm{yr}$ & $11 / 26$ & $\begin{array}{l}\mathrm{I}-30 \mathrm{mo} \\
(8 \mathrm{mo})\end{array}$ & $13-68.5$ & $\geq 50 \%$ red: 8 (72\%) \\
\hline $\begin{array}{l}\text { Grosso } \\
2005^{18}\end{array}$ & $\begin{array}{l}\text { Open-label, } \\
\text { prospective, add-on }\end{array}$ & $\mathrm{RE}$ & $6 \mathrm{mo}-16 \mathrm{yr}$ & $53 / 110$ & $\begin{array}{l}\text { 2-20 mo } \\
\text { (median: } 7 \mathrm{mo} \text { ) }\end{array}$ & $10-60$ & $\begin{array}{l}\text { Sz free: } 6(11.3 \%) \\
\leq 50 \% \text { red: } 25(47.2 \%)\end{array}$ \\
\hline $\begin{array}{l}\text { Lagae } \\
2005^{3}\end{array}$ & $\begin{array}{l}\text { Open-label, } \\
\text { prospective, } \\
\text { add-on and } \\
\text { monotherapy }\end{array}$ & $\mathrm{RE}$ & $6 \mathrm{mo}-16 \mathrm{yr}$ & $\begin{array}{l}\text { Add-on: 31/67 } \\
\text { Mono: 4/10 }\end{array}$ & $20 w$ & $\begin{array}{l}12-62 \\
\text { (median 33) }\end{array}$ & $\begin{array}{l}\text { Add-on } \\
\text { Sz free: } 2(6 \%) \\
\geq 50 \% \text { red: } 16(51 \%) \\
\text { Monotherapy } \\
\text { Sz free: I }(25 \%) \\
\geq 50 \% \text { red: } 4(100 \%)\end{array}$ \\
\hline $\begin{array}{l}\text { Mandelbaum } \\
2005^{5}\end{array}$ & $\begin{array}{l}\text { Retrospective, } \\
\text { add-on and } \\
\text { monotherapy }\end{array}$ & RE & $9 \mathrm{mo}-23 \mathrm{yr}$ & $15 / 59$ & $12 \mathrm{mo}$ & I I.36-227.27 & $\begin{array}{l}\text { Sz free: } 5(33 \%) \\
50 \%-90 \% \text { red: I (7\%) } \\
<50 \% \text { red: } 9(60 \%)\end{array}$ \\
\hline Opp $2005^{4}$ & $\begin{array}{l}\text { Open-label, } \\
\text { prospective, add-on }\end{array}$ & $\mathrm{RE}$ & $<8 \mathrm{yr}$ & $134 / 285$ & $\begin{array}{l}\text { I2-86 w } \\
\text { (median: } 33 \text { w) }\end{array}$ & $\begin{array}{l}\text { Varied, } \max \\
\text { dose }=47.4+21.8\end{array}$ & $\geq 50$ red: 35 (26.1\%) \\
\hline $\begin{array}{l}\text { Glauser } \\
2006^{6}\end{array}$ & $\begin{array}{l}\text { Randomized, } \\
\text { double-blind, } \\
\text { placebo- } \\
\text { controlled, add-on }\end{array}$ & POS & $4-16 \mathrm{yr}$ & 198/198 & $14 w$ & 60 & $\begin{array}{l}\text { Sz free } \\
\text { LEV: } 7(6.9 \%) \\
\text { Placebo: I (I\%) } \\
\geq 50 \% \text { red } \\
\text { LEV: } 45(44.6 \%) \\
\text { Placebo: } 19(19.6 \%)\end{array}$ \\
\hline $\begin{array}{l}\text { Coppola } \\
2007^{51}\end{array}$ & $\begin{array}{l}\text { Open-label, } \\
\text { prospective, } \\
\text { randomized, } \\
\text { monotherapy }\end{array}$ & $\begin{array}{l}\text { POS w/ } \\
\text { BECTS }\end{array}$ & $3-14 \mathrm{yr}$ & $21 / 39$ & $\begin{array}{l}\text { I2-24 mo } \\
(18.5 \mathrm{mo})\end{array}$ & 20 or 30 & $\begin{array}{l}\text { Sz free @ } 18 \text { mo } \\
\text { LEV: } 19(90.5 \%) \\
\text { OXC: } 13(72.2 \%)\end{array}$ \\
\hline $\begin{array}{l}\text { Fountain } \\
2007^{24}\end{array}$ & $\begin{array}{l}\text { Open-label, } \\
\text { prospective, add-on }\end{array}$ & POS & $4-12 y r$ & $21 / 21$ & $10 w$ & $20-60$ & $\geq 50 \%$ red: 9 (43\%) \\
\hline $\begin{array}{l}\text { Grosso } \\
2007^{35}\end{array}$ & $\begin{array}{l}\text { Retrospective, } \\
\text { add-on }\end{array}$ & $\mathrm{RE}$ & $<4 \mathrm{yr}$ & $30 / 81$ & $\begin{array}{l}3-42 \mathrm{mo} \\
(9 \mathrm{mo})\end{array}$ & $25-62$ & $\begin{array}{l}\text { Sz free: } 6(20 \%) \\
\geq 50 \% \text { red: II (37\%) }\end{array}$ \\
\hline $\begin{array}{l}\text { Callenbach } \\
2008^{9}\end{array}$ & $\begin{array}{l}\text { Open-label, } \\
\text { prospective, add-on }\end{array}$ & $\mathrm{RE}$ & $4-16 \mathrm{yr}$ & $19 / 33$ & $26 w$ & $9-53$ (mean -26$)$ & $\begin{array}{l}\text { Sz free for } \geq 4 \mathrm{w}: 7 \\
\geq 50 \% \text { red: } 1 \mathrm{I}\end{array}$ \\
\hline Cilio $2009^{41}$ & $\begin{array}{l}\text { Case series, } \\
\text { add-on }\end{array}$ & MPSI & $3 \mathrm{mo}, 9 \mathrm{mo}$ & $2 / 2$ & $10 \mathrm{mo}, 16 \mathrm{mo}$ & $\begin{array}{l}\text { Loading: } 60 \mathrm{mg} / \mathrm{kg} \\
\text { Maintain: } 30 \mathrm{mg} / \mathrm{kg} \\
\text { (BID) }\end{array}$ & $\begin{array}{l}\text { SE stopped within } \\
12 \mathrm{~h}\end{array}$ \\
\hline $\begin{array}{l}\text { Kirmani } \\
2009^{42}\end{array}$ & $\begin{array}{l}\text { Retrospective, } \\
\text { add-on and } \\
\text { monotherapy }\end{array}$ & SE/ASE & $2 \mathrm{mo}-18 \mathrm{yr}$ & $29 / 32 * *$ & $24-48 \mathrm{~h}$ & $\begin{array}{l}\text { Loading: } 50 \mathrm{mg} / \mathrm{kg} \\
(25) ; 25 \mathrm{mg} / \mathrm{kg}(4) ; \\
60 \mathrm{mg} / \mathrm{kg}(2) ; \\
70 \mathrm{mg} / \mathrm{kg}(\mathrm{I}) \\
\text { Maintain: } \\
25 \mathrm{mg} / \mathrm{kg} / \mathrm{I} 2 \mathrm{~h}\end{array}$ & $\begin{array}{l}\text { All responded clinically } \\
\text { and on EEG within } \\
25-30 \text { min of infusion }\end{array}$ \\
\hline $\begin{array}{l}\text { Levisohn } \\
2009^{30}\end{array}$ & $\begin{array}{l}\text { Randomized, } \\
\text { double-blind, } \\
\text { placebo-controlled, } \\
\text { add-on }\end{array}$ & POS & $4-16 \mathrm{yr}$ & $98 / 98$ & $12 \mathrm{w}$ & $20-60$ & $\begin{array}{l}\text { Sz free } \\
\text { LEV: } 30 \text { (46.9\%) } \\
\text { Placebo: } 3(8.8 \%) \\
\geq 50 \% \text { red } \\
\text { LEV: } 40(62.5 \%) \\
\text { Placebo: } 14(41.2 \%)\end{array}$ \\
\hline $\begin{array}{l}\text { Pina-Garza } \\
2009^{10}\end{array}$ & $\begin{array}{l}\text { Randomized, } \\
\text { double-blind, } \\
\text { placebo-controlled, } \\
\text { add-on }\end{array}$ & POS & $\mathrm{I} \mathrm{mo}-<4 \mathrm{yr}$ & $116 / 116$ & $5 d$ & $\begin{array}{l}40 \text { (<6 mo); } \\
50(>6 \mathrm{mo})\end{array}$ & $\begin{array}{l}\geq 50 \% \text { red } \\
\text { LEV: } 25(43.1 \%) \\
\text { Placebo: } 10(19.6 \%)\end{array}$ \\
\hline
\end{tabular}


Table I (Continued)

\begin{tabular}{|c|c|c|c|c|c|c|c|}
\hline Study & Trial design & Diagnosis & Ages & POS/total \#* & $\begin{array}{l}\text { Duration } \\
\text { (mean) }\end{array}$ & $\begin{array}{l}\text { Dosage } \\
(\mathrm{mg} / \mathrm{kg} / \mathrm{d})\end{array}$ & Efficacy*** \\
\hline $\begin{array}{l}\text { Pina-Garza } \\
2010^{31}\end{array}$ & $\begin{array}{l}\text { Open-label, } \\
\text { prospective, } \\
\text { long-term add-on }\end{array}$ & POS & $1 \mathrm{mo}-<4 \mathrm{yr}$ & $152 / 152$ & $\begin{array}{l}30-48 w \\
(4 I w)\end{array}$ & $20-80$ & $\begin{array}{l}\text { Sz free } \geq 24 \text { w: } 10(7.6 \%) \\
\geq 50 \% \text { red: } 7 \text { I }(53.8 \%)\end{array}$ \\
\hline $\begin{array}{l}\text { Chhun } \\
2011^{36}\end{array}$ & $\begin{array}{l}\text { Open-label, } \\
\text { prospective, } \\
\text { add-on }\end{array}$ & $\begin{array}{l}\text { POS, GS, } \\
\text { CSWS }\end{array}$ & $6 \mathrm{mo}-15 \mathrm{yr}$ & $37 / 102$ & $6 \mathrm{mo}$ & $40-60$ & $\begin{array}{l}\geq 50 \% \text { red @ } 3 \text { mo } \\
\text { POS: } 14(39 \%) \\
\text { CSWS: } 4(80 \%) \\
\text { (3 sz free, I 92\% red) } \\
>50 \% \text { red @ } 6 \text { mo } \\
\text { POS: } 9 \text { (25\%) } \\
\text { CSWS: } 4(80 \%)\end{array}$ \\
\hline $\begin{array}{l}\text { McTague } \\
2012^{43}\end{array}$ & $\begin{array}{l}\text { Open-label, } \\
\text { prospective, } \\
\text { acute IV } \\
\text { administration, } \\
\text { add-on and } \\
\text { monotherapy }\end{array}$ & $\begin{array}{l}\text { ARS, CSE, } \\
\text { NCSE }\end{array}$ & $2 \mathrm{mo}-18 \mathrm{yr}$ & $27 / 51$ & $0-18 \mathrm{mo}$ & $\begin{array}{l}\text { Initial dose: } \\
5-30 \mathrm{mg} / \mathrm{kg} \\
\text { Maintain: } \\
10-25 \mathrm{mg} / \mathrm{kg}\end{array}$ & $\begin{array}{l}\text { Sz free: } 18(67 \%) \\
\geq 50 \% \text { red: } 5(18.5 \%)\end{array}$ \\
\hline $\begin{array}{l}\text { Schiemann- } \\
\text { Delgado } \\
2012^{11}\end{array}$ & $\begin{array}{l}\text { Open-label, } \\
\text { prospective, } \\
\text { long-term add-on }\end{array}$ & POS & $4-16 \mathrm{yr}$ & $103 / 103$ & $48 w$ & $20-100$ & $\begin{array}{l}\text { Sz free } 12 \text { w: } 3 \text { I }(33.4 \%) \\
\text { Sz free } 24 \text { w: } 26(28 \%) \\
\text { Sz free } 40 \text { w: } 10(24.7 \%) \\
\geq 50 \% \text { red: } 65(69 \%)\end{array}$ \\
\hline
\end{tabular}

Notes: *Because some studies included other seizure types and/or adult patients, we provide a fraction of patients under 18 with POS/total number of enrolled patients; **includes partial and partial with secondary generalization; ***efficacy reports are only for subjects under 18 years old with POS.

Abbreviations: ARS, acute repetitive seizure; ASE, acute seizure exacerbation; BECTS, benign epilepsy with centrotemporal spikes; BID, twice daily; CSE, convulsive status epilepticus; CSWS, continuous spike and wave activity in slow wave sleep; EEG, electroencephalography; Eval, evaluation; GS, generalized seizure; LEV, levetiracetam; Mono, monotherapy; MPSI, migrating partial seizure of infancy; NCSE, non-convulsive status epilepticus; OXC, oxcarbazepine; POS, partial onset seizure; RE, refractory epilepsy; Red, reduction; SE, status epilepticus; Sz, seizure.

Patients were given a loading dose of $25-70 \mathrm{mg} / \mathrm{kg}$ and a maintenance dose of $25 \mathrm{mg} / \mathrm{kg}$ every 12 hours, and no serious side effects were reported. In contrast, in a separate study evaluating children (aged 2 months to 18 years), $\mathrm{n}=27$ of 51 suffering from acute repetitive seizures with partial onset, only $62 \%$ of patients receiving a lower loading dose of levetiracetam $(5-30 \mathrm{mg} / \mathrm{kg})$ saw alleviation of their acute repetitive seizures, with three patients experiencing aggression and one discontinuing levetiracetam as a result. ${ }^{43}$ At follow-up, $64 \%$ of all study participants (including both subjects with partial and those with generalized seizures) remained seizurefree, and $82 \%$ of patients remained on oral levetiracetam.

\section{Efficacy as monotherapy}

While levetiracetam is not currently approved by the FDA for use as monotherapy, some studies have shown it to be an effective and well tolerated treatment option in adults with refractory partial epilepsy. ${ }^{44,45} \mathrm{Few}$ studies have investigated the efficacy of levetiracetam monotherapy for partial onset seizures in the pediatric population. Two small case series found that four of four children (aged 6 months to 16 years) and ten of 14 children (aged 2-18 years) ${ }^{46}$ with partial seizures responded to levetiracetam monotherapy. One larger retrospective study identified 86 children under 16 years of age with partial seizures being treated with either levetiracetam or carbamazepine monotherapy for at least 6 months. ${ }^{8}$ Of the 66 patients on levetiracetam monotherapy, $48(73 \%)$ were seizure-free at 6 months compared with 13 of $20(65 \%)$ patients on carbamazepine monotherapy. However, levetiracetam was better tolerated than carbamazepine in these patients. Randomized controlled studies in children are required to evaluate further the efficacy of levetiracetam in this population.

\section{Efficacy in special populations}

To date, 28 distinct electroclinical syndromes have been described in children, and tailoring medication choice based on efficacy for specific epilepsy syndromes may result in improved efficacy. ${ }^{47-49}$ Few studies have evaluated the efficacy of levetiracetam in particular pediatric electroclinical syndromes. Here we review the available data examining levetiracetam use in benign epilepsy with centrotemporal spikes (BECTS), tuberous sclerosis complex, and continuous spike and wave activity during sleep.

\section{Benign epilepsy with centrotemporal spikes}

BECTS is one of the most common childhood epilepsies, with a prevalence of $10 \%-24 \%$ in pediatric patients with epilepsy. ${ }^{50}$ Seizure frequency in BECTS is typically low, although some patients can experience multiple 
seizures per day. ${ }^{50}$ Seizures tend to occur during sleep ${ }^{51}$ and remit by adolescence in $98 \%$ of patients. ${ }^{50}$ Despite the relatively benign nature and generally excellent prognosis of BECTS, some patients require treatment to reduce the psychosocial and medical morbidities associated with recurrent seizures. Moreover, there is some evidence to suggest that BECTS may not be completely benign; several studies have reported deficits in fine motor control, executive function, and memory in these patients. ${ }^{52-54}$ Preliminary data suggest that levetiracetam may be an effective treatment for seizures in BECTS. In a prospective randomized, open-label trial of levetiracetam versus oxcarbazepine monotherapy in children aged $5-13$ years $(n=21)$ with BECTS, $90 \%$ of patients on levetiracetam showed seizure freedom at 18 months..$^{51}$ This was slightly higher than the $72 \%$ of patients who achieved seizure freedom on oxcarbazepine. ${ }^{51}$ These preliminary results suggest that levetiracetam is a reasonable option for children with BECTS seeking treatment.

\section{Tuberous sclerosis complex}

Tuberous sclerosis complex is an autosomal dominant genetic disorder with a wide variety of clinical symptoms, commonly including seizures. Patients with tuberous sclerosis complex can exhibit a variety of seizure types, including both simple and complex partial seizures, which are often refractory to anticonvulsant treatment. ${ }^{55}$ One retrospective study looked at the effects of adjunctive levetiracetam on seizure control in 20 children aged 2-19 years with tuberous sclerosis complex, all of whom had complex partial seizures. The results of this study were in line with those for studies in other pediatric populations (Table 1), with $40 \%$ of patients experiencing greater than $50 \%$ reduction in seizure frequency. ${ }^{56}$ The range and frequency of side effects also matched that for the general population of infants and children with partial seizures on levetiracetam, with aggression, irritability, and sleep disturbances being the most common side effects. Side effects were seen more in patients who did not respond to levetiracetam treatment than in responders. ${ }^{56}$

\section{Continuous spike and wave activity during slow wave sleep}

Epileptic encephalopathy with continuous spike and wave activity during slow wave sleep is a rare and challenging epilepsy syndrome characterized by a high burden of spikes during sleep associated with both focal and generalized seizures as well as neuropsychological dysfunction..$^{57,58}$
In many cases, electrographic spike activity progresses in frequency over time and may correlate with cognitive decline. ${ }^{57,58}$ Data from two small prospective, open-label trials evaluated adjunctive use of levetiracetam in children aged 4-11 years with continuous spike and wave activity during sleep ( $n=6$ in both). ${ }^{36,59}$ In one trial, $83 \%$ achieved $>50 \%$ seizure reduction as well as psychomotor improvements and complete electroencephalographic normalization with addition of levetiracetam. ${ }^{59}$ In the second trial, $67 \%$ of children experienced $\geq 50 \%$ seizure reduction, with half of these children showing electroencephalographic normalization and half showing unchanged spiking activity. The vast majority of subjects in these trials experienced both focal and generalized seizures. Capovilla et al ${ }^{60}$ reported two patients (aged 11 years and 4 years) with focal epilepsy and pharmacoresistant continuous spike and wave activity during sleep. In both cases, this abated within 40 days of treatment with levetiracetam, and both patients achieved seizure freedom, reduced spikes on electroencephalography, and improved performance on neuropsychiatric testing. ${ }^{60}$

\section{Neonates}

While not currently indicated for use in neonates, levetiracetam has been increasingly used to treat seizures in this population. Although limited, preliminary safety and efficacy data for use of levetiracetam in neonates seem promising. In one prospective, open-label trial of intravenous levetiracetam in neonates with both partial and generalized seizures $(n=38$, gestational ages 23-42 weeks), 30 of 38 patients were seizurefree at one week, and 27 remained seizure-free at 4 weeks. ${ }^{61}$ Somnolence during titration was the only adverse event reported (exact number not stated), although 19 newborns required a dose of phenobarbital $(20 \mathrm{mg} / \mathrm{kg})$ within 48 hours of treatment onset for seizure recurrence. Another prospective, open-label trial studying oral levetiracetam monotherapy in six neonates (gestational age 31-41 weeks) showed similar efficacy, with all six newborns achieving seizure freedom within 6 days and four of the six remaining seizure-free at 3 months. ${ }^{62}$ Somnolence during titration was reported in one newborn. Data from retrospective studies of intravenous levetiracetam (10-60 mg/kg/day) are mixed, with one trial $(\mathrm{n}=22$ ) showing seizure freedom in $100 \%$ of subjects within 72 hours, ${ }^{63}$ and another $(\mathrm{n}=23)$ showing that only $35 \%$ of newborns achieved $\geq 50 \%$ seizure reduction. ${ }^{64}$ While these data suggest that levetiracetam may be a safe and effective treatment for neonatal seizures, no randomized controlled trials have been performed and more work is needed before definitive conclusions can be made. 


\section{Safety and tolerability \\ Preclinical data}

Increasing evidence suggests that anticonvulsant drug exposure during critical periods of brain development may adversely affect nervous system function and this is a significant concern for all new anticonvulsant drugs. ${ }^{65}$ Although no definitive data from human studies are available, preclinical data for levetiracetam has been promising. Levetiracetam has been shown not to induce neuronal death in 7-day-old rat pups either when given alone ${ }^{66,67}$ or in combination with carbamazepine ${ }^{67}$ Of carbamazepine, topiramate, phenytoin, and levetiracetam, levetiracetam was the only drug that did not exacerbate phenytoin-induced cell death when coadministered ${ }^{67}$ In another study of phenytoin, phenobarbital, lamotrigine, and levetiracetam, levetiracetam was the only drug that did not interrupt synaptic development when given in the postnatal period. ${ }^{68}$

\section{Clinical data}

\section{Behavioral and cognitive side effects}

In clinical studies, levetiracetam has been shown to be an effective and well tolerated therapy for most pediatric patients with partial onset seizures. ${ }^{3,5,9,10,23,30,32,34-37}$ The majority of side effects are reported as mild to moderate and can often be alleviated by dose adjustment, only rarely resulting in discontinuation of levetiracetam. Safety data across studies depict a similar pattern of adverse effects, with the most commonly reported including somnolence, observed in $2 \%-49 \%$ of patients, ${ }^{3-6,10,31,34,35,37,38}$ and behavioral changes, including aggression, irritability, and mood changes, observed in 1\%-39\% of patients t $^{3-6,9,11,31,38}$ (Table 2). While adverse effects rarely led to discontinuation of levetiracetam in any trial, of those that did, behavioral changes were the most common cause, in one study prompting discontinuation of levetiracetam in up to $8 \%$ of patients. ${ }^{4}$

In three prospective, open-label trials of levetiracetam in children under 16 years $\left(n=25,{ }^{38} n=31,{ }^{3} n=53{ }^{18}\right), 6 \%-29 \%$ of children experienced behavioral changes, decreased alertness, or impaired concentration, yet in these same trials, parents reported improvements in these areas in 17\%-25\% of children on levetiracetam that did not correlate with improved seizure frequency. Improvements in these studies were anecdotal. De la Loge et a ${ }^{32}$ used the Achenbach Child Behavior Checklist and portions of the CHQ-PF50 tool to assess behavioral and emotional functioning in 98 children aged 4-16 years with partial onset seizures. Many patients in this trial exhibited behavioral problems at baseline, although a large and statistically significant worsening of behavior was seen in patients on levetiracetam compared with placebo in the aggressive behavior category, driven by items like "argues a lot", "mean to others", "screams a lot", and "disobedient at home". ${ }^{32}$ In a long-term, open-label follow-up to this study, Schiemann-Delgado et al showed statistically significant improvement from baseline in the aggressive behavior category in children on levetiracetam. ${ }^{11}$ While efficacy rates (69.1\% had $\geq 50 \%$ seizure reduction) were consistent from the prior 12-week trial (62.5\% responders) ${ }^{30}$ it is unknown how improvements in aggressive behavior correlated with improvements in seizure control. In additional, dosing was flexible in this trial, ${ }^{11}$ suggesting that behavioral side effects may be at least partially alleviated by adjusting the levetiracetam dose.

One double-blind, randomized, placebo-controlled trial of adjunctive levetiracetam $(20-60 \mathrm{mg} / \mathrm{kg} /$ day $)$ measured cognitive changes over 12 weeks in children aged 4-16 years with partial seizures $(\mathrm{n}=98) \cdot{ }^{30}$ Cognitive changes were assessed using the Leiter-R and WRAML-2 (Wide Range Assessment of Memory and Learning) scales administered by a blinded neuropsychiatrist. The Leiter- $\mathrm{R}$ is a nonverbal scale used to evaluate memory and attention in children. ${ }^{30}$ The WRAML-2 evaluates learning and memorization ability in children and distinguishes between verbal, visual, and global memory deficits. This trial showed no difference in neurocognitive effects between patients on levetiracetam and those on placebo. A long-term follow-up to this trial showed stability of cognitive function using the same assessment scales at 24 and 48 weeks. ${ }^{11}$ A separate 48 -week, open-label study of adjunctive levetiracetam in children aged from one month to 4 years with partial onset seizures found no impact of levetiracetam on behavior or psychomotor scores using the BSID-II (Bayley Scales of Infant Development) designed to assess cognitive, behavior, and psychomotor development in young children. ${ }^{31}$

Other common side effects of levetiracetam include sleep disturbances $(1 \%-33 \%),{ }^{4,10,31,34}$ anorexia $\left.(1 \%-18 \%),\right)^{3,4,6,9,34}$ nausea $(2 \%-12 \%),{ }^{4,5,9,10,31}$ and headache $(1 \%-33 \%)^{3,5,9,11,34,38}$ (Table 2). Extremely rare but potentially serious side effects have been reported, including serious psychiatric disturbances, ${ }^{69-71}$ choreoathetosis, ${ }^{18}$ and hemorrhagic colitis. ${ }^{4}$ However, in each case, these effects were reversed with discontinuation of levetiracetam.

\section{Psychosis}

While levetiracetam has been shown to be well tolerated by most, rare cases of levetiracetam-induced psychosis in pediatric patients have been reported. Kossoff et al 
Table 2 Adverse effects reported in trials of LEV in infants and children with epilepsy

\begin{tabular}{|c|c|c|c|}
\hline Study & Ages & Top 3 AE's (\%)* & Other AE's (>5\% prev) \\
\hline Kossoff 200169 & $5-17$ yr (case series) & Acute psychosis & \\
\hline Glauser $2002^{34}$ & $6-12 \mathrm{yr}$ & $\begin{array}{l}\text { HA (33.3), URI (33.3), somnolence/fatigue (25), } \\
\text { anorexia (25) }\end{array}$ & $\begin{array}{l}\text { Sleep problems, general behavioral, } \\
\text { Pyrexia, nasopharyngitis, convulsion, } \\
\text { nervousness, diarrhea, otitis media }\end{array}$ \\
\hline Wheless $2002^{38}$ & $6 \mathrm{mo}-14 \mathrm{yr}$ & $\begin{array}{l}\text { Somnolence/fatigue (I5.4), aggression (I2.8), } \\
\text { gen behavioral (38.5)** }\end{array}$ & $\begin{array}{l}\mathrm{HA} \text {, cognitive disturbance, } \\
\text { hyperactivity, decreased } \\
\text { concentration }\end{array}$ \\
\hline Youroukos $2003^{70}$ & 12 yr (case report) & Acute psychosis & \\
\hline $\operatorname{Tan} 2004^{37}$ & $<10 \mathrm{yr}$ & N/A & \\
\hline Grosso $2005^{18}$ & $6 \mathrm{mo}-16 \mathrm{yr}$ & Somnolence/fatigue (14), irritability (14) & \\
\hline Lagae $2005^{3}$ & $6 \mathrm{mo}-16 \mathrm{yr}$ & Somnolence/fatigue (7.8), aggression (5) & \\
\hline Mandelbaum $2005^{5}$ & $9 \mathrm{mo}-23 \mathrm{yr}$ & Aggression (32), somnolence/fatigue (20) & \\
\hline Opp $2005^{4}$ & $<18 \mathrm{yr}$ & $\begin{array}{l}\text { Somnolence/fatigue (24), aggression (I0.5), } \\
\text { gen behavioral (5) }\end{array}$ & \\
\hline Coppola $2007^{51}$ & $3-14 \mathrm{yr}$ & Anorexia (I4.3) & \\
\hline Grosso $2007^{35}$ & $<4 \mathrm{yr}$ & $\begin{array}{l}\text { Somnolence/fatigue (45), nervousness (36), } \\
\text { cognitive disturbance (29) }\end{array}$ & Anorexia \\
\hline Callenbach $2008^{9}$ & $4-16 \mathrm{yr}$ & $\begin{array}{l}\text { Somnolence/fatigue (48.5), hyperactivity (33.3), } \\
\text { irritability (30.3) }\end{array}$ & $\begin{array}{l}\text { Aggression, anorexia, HA, nausea/ } \\
\text { vomit, general behavioral, cognitive } \\
\text { disturbance, constipation, nervousness, } \\
\text { decreased concentration, tremor, } \\
\text { weight change, drooling, hair loss, } \\
\text { problems with gums }\end{array}$ \\
\hline Pina-Garza $2009^{10}$ & $\mathrm{I} \mathrm{mo}-<4 \mathrm{yr}$ & $\begin{array}{l}\text { Somnolence/fatigue (I3.3), irritability (II.7), } \\
\text { Pyrexia (5) }\end{array}$ & \\
\hline Tamarelle $2009^{71}$ & $5 \mathrm{yr}$ (case report) & Depression & \\
\hline Pina-Garza $2010^{31}$ & $\mathrm{Imo}-<4 \mathrm{yr}$ & Pyrexia (39.5), URI (27.6), nausea/vomit (18.4) & $\begin{array}{l}\text { Somnolence/fatigue, sleep } \\
\text { problems, irritability, constipation, } \\
\text { nasopharyngitis, convulsion, otitis } \\
\text { media }\end{array}$ \\
\hline Chhun $20 \mathrm{II}^{36}$ & $6 \mathrm{mo}-15 \mathrm{yr}$ & $\begin{array}{l}\text { Hyperactivity (14.6), somnolence/fatigue (9.7), } \\
\text { sleep problems (8.7) }\end{array}$ & Anorexia \\
\hline $\begin{array}{l}\text { Schiemann-Delgado } \\
2012^{\prime \prime}\end{array}$ & $4-16 \mathrm{yr}$ & HA (24.3), pyrexia (23.3), URI (2I.4) & $\begin{array}{l}\text { Upper abdominal pain, somnolence/ } \\
\text { fatigue, aggression, nausea/vomit, general } \\
\text { behavioral, irritability, convulsion, } \\
\text { nasopharyngitis, diarrhea, rash }\end{array}$ \\
\hline
\end{tabular}

Notes: *Only AE's with $\geq 5 \%$ prevalence reported here; **number of included patients with aggression-related AE.

Abbreviation: AE, Adverse effect; HA, headache; LEV, levetiracetam; N/A, No side effects with $>5 \%$ prevalence reported; URI, upper respiratory infection.

reported on four patients, aged 5-17 years, who developed reversible psychosis after initiation of levetiracetam. ${ }^{69}$ In all but one case, levetiracetam had been titrated rapidly. In all cases, patients had a history of behavioral or cognitive abnormalities (including mental retardation, depression, and oppositional behavior to authority and family), and in all cases, symptoms of psychosis were completely resolved with discontinuation of levetiracetam. Youroukos et al reported similar development of agitation, hallucinations, and selfharming behavior in a 13-year-old girl with partial onset seizures on concomitant sodium valproate with no history of cognitive or behavioral disturbances. ${ }^{70}$ This patient was also titrated quickly (over ten days) to a dose of $60 \mathrm{mg} / \mathrm{kg} /$ day, and her psychosis completely resolved within one week of discontinuing levetiracetam.

\section{Depression}

Two studies have systematically measured depression in pediatric patients with epilepsy on levetiracetam using standardized tools. Both suggest that depression either remains stable from a baseline pre-levetiracetam state or improves slightly with addition of levetiracetam (age 4-16 years, $\mathrm{n}=98 ;^{32}$ age $4-16$ years, $\mathrm{n}=103^{11}$ ). However, there has been one case report of a major depressive episode in a 5-year-old boy with partial seizures and no prior history of psychiatric or behavioral symptoms. ${ }^{71}$ The patient was treated concurrently with lamotrigine, and 3 weeks after initiation of levetiracetam, he began experiencing lack of appetite, insomnia, fatigue, irritability, loss of interest in fun activities, prolonged periods in bed, and aggressive behavior at school. Symptoms persisted for 4 weeks and resolved on discontinuation of levetiracetam. 


\section{Suicidality}

In 2008, the FDA issued a warning regarding an increased risk of suicidality in patients on anticonvulsant drugs for any of three different indications, including epilepsy. Data published on the topic since the warning was issued has been contradictory at best, with the most conclusive statement issued in 2012 by the International League Against Epilepsy concluding that it is impossible to determine from published studies whether anticonvulsant drugs are associated with suicidal behavior. ${ }^{72}$ Still, patients with epilepsy are at threefold greater risk of committing suicide, ${ }^{73}$ and given the link between suicidal behavior in epilepsy and increased impulsivity and aggression, ${ }^{74}$ and in light of the behavioral adverse effects associated with levetiracetam, suicidality is a potential concern. That said, we were unable to identify any evidence that children and adolescents taking levetiracetam have increased rates of suicidal ideation or behavior.

\section{Dose adjustment}

It remains unclear whether the adverse side effects associated with levetiracetam are dose-dependent. One prospective study of levetiracetam $(n=31)$ found higher rates of adverse effects in patients taking $>45 \mathrm{mg} / \mathrm{kg} / \mathrm{day},{ }^{3}$ whereas two other retrospective chart reviews $\left(n=32^{19}\right.$ and $\left.n=15^{5}\right)$ did not find that tolerability of levetiracetam is dose-dependent. Rapid titration of levetiracetam (1-14 days) can be well tolerated, although adverse effects were observed in $12 \%-22 \%$ of subjects. ${ }^{10,75}$

\section{Pyridoxine}

Many practitioners anecdotally report improved behavioral side effects of levetiracetam with vitamin B6 (pyridoxine) supplementation, but few studies have evaluated this systematically. Using retrospective chart review and patient questionnaires, Major et al found that, of patients aged 3-19 years on levetiracetam for an average of 6 months who experienced behavioral side effects, $41 \%$ saw significant behavioral improvement with pyridoxine, $36 \%$ saw no change, and $18 \%$ reported worsening of behavioral symptoms. ${ }^{76}$ Patients who initiated levetiracetam and pyridoxine at the same time did not show evidence of improvement in behavioral symptoms, perhaps reflecting either wide individual variation or a placebo effect. For accurate interpretation, placebo-controlled studies are required to confirm the efficacy of pyridoxine supplementation.

\section{Summary}

The ultimate charge for all child neurologists is to support normal brain function through the period of immense cognitive and behavioral growth that occurs over development. This challenging task becomes nearly impossible when the risks and benefits of the medications at hand to treat pediatric disease are unknown. Longstanding concerns have been raised that some anticonvulsants may have toxic effects on early neuronal development. ${ }^{66-68}$ Recent evidence also suggests that properties specific to the developing brain may render some anticonvulsants ineffective or potentially even proconvulsant when administered during early development. ${ }^{77,78}$ Although there has been a dramatic increase in the number of anticonvulsants approved by the FDA for use in the US over the last two decades, limited information is available regarding the safety and efficacy of these medications in the pediatric population, and it is increasingly clear that safety and efficacy data do not directly translate from adult studies to pediatric populations. ${ }^{79}$

Recent trends in clinical research and drug development are encouraging for pediatric epilepsy. Study designs are beginning to reflect the heterogeneity of the pediatric population, with clinical studies now distinguishing between infants ${ }^{10,31,35}$ versus school-aged children ${ }^{24,34,37,38}$ and adolescents. ${ }^{3,4,6,9,11,18,30}$ In recent years, the FDA has implemented both voluntary and mandatory initiatives to stimulate and improve medical product research in children. These include the Best Pharmaceuticals for Children Act and the Pediatric Research Equity Act. The former provides economic incentive for companies to conduct studies in children as requested by the FDA by offering an additional 6 months of marketing exclusivity for all formulations containing a given active ingredient. ${ }^{79}$ The latter allows the FDA to mandate that pediatric studies be conducted for a new drug if it determines that the product is likely to be used in children. ${ }^{79}$ In response, many of the recently approved anticonvulsant drugs include or specifically target pediatric epilepsy populations. Vigabatrin and nonsynthetic adrenocorticotropic hormone were approved in 2009 and 2010, respectively, for use in infants and children under 2 years of age with infantile spasms, a rare and severe epilepsy syndrome. Two drugs have recently been approved for treatment of Lennox-Gastaut syndrome, another challenging and severe pediatric epilepsy syndrome; rufinamide in 2008 for children from 4 years of age and clobazam in 2011 for children from 2 years of age. Most recently, in 2012, the FDA approved perampanel for use as adjunctive therapy in children from 12 years of age with partial seizures and extended its approval of levetiracetam for partial seizures to include children from one month of age. 
As reviewed here, the current data leading to approval of levetiracetam for use in infants and children with partial onset seizures are encouraging. Existing data suggest that levetiracetam may be a safe and effective treatment option for children and infants with partial seizures from a variety of etiologies and that these findings may be consistent across age groups. However, more work remains to be done. Of the three randomized controlled trials of levetiracetam conducted in children with partial seizures, ${ }^{10,30,32}$ only one of these included infants and children under the age of 4 years, very few of whom were between one and 6 months of age. ${ }^{10}$ More data are needed before definitive conclusions can be drawn about the efficacy of levetiracetam across different pediatric age groups. Further, very few studies have systematically examined either the immediate or long-term cognitive and neurobehavioral effects of levetiracetam in children. ${ }^{11,30,32}$ The existing data suggest that levetiracetam is not likely to cause cognitive deficits, but only a single study has evaluated cognitive impact in the younger age groups. ${ }^{31}$

Given the dynamic anatomical and physiological changes that the maturing brain undergoes over the course of development, teasing out the safety and efficacy of anticonvulsant medication at different stages of brain development is an arduous and complex process. Recent trends, including those that led to the approval of levetiracetam for partial seizures across infancy and childhood, suggest that the tip of the iceberg has been struck and may signify increasing momentum to identify safe and effective treatments for children with epilepsy.

\section{Disclosure}

The authors report no conflicts of interest in this work.

\section{References}

1. Shinnar S, Pellock JM. Update on the epidemiology and prognosis of pediatric epilepsy. J Child Neurol. 2002;17 Suppl 1:S4-S17.

2. CDC. Targeting epilepsy: Improving the lives of people with one of the nation's most common neurological conditions. 2011. Available from: http://www.cdc.gov/chronicdisease/resources/publications/AAG/ epilepsy.htm. Accessed January 23, 2013.

3. Lagae L, Buyse G, Ceulemans B. Clinical experience with levetiracetam in childhood epilepsy: an add-on and mono-therapy trial. Seizure. 2005;14(1):66-71.

4. Opp J, Tuxhorn I, May T, et al. Levetiracetam in children with refractory epilepsy: a multicenter open label study in Germany. Seizure. 2005;14(7): 476-484.

5. Mandelbaum DE, Bunch M, Kugler SL, Venkatasubramanian A, Wollack JB. Efficacy of levetiracetam at 12 months in children classified by seizure type, cognitive status, and previous anticonvulsant drug use. J Child Neurol. 2005;20(7):590-594.

6. Glauser TA, Ayala R, Elterman RD, et al. Double-blind placebocontrolled trial of adjunctive levetiracetam in pediatric partial seizures. Neurology. 2006;66(11):1654-1660.
7. Perry MS, Benatar M. Efficacy and tolerability of levetiracetam in children younger than 4 years: a retrospective review. Epilepsia. 2007;48(6):1123-1127.

8. Perry S, Holt P, Benatar M. Levetiracetam versus carbamazepine monotherapy for partial epilepsy in children less than 16 years of age. J Child Neurol. 2008;23(5):515-519.

9. Callenbach PM, Arts WF, ten Houten R, et al. Add-on levetiracetam in children and adolescents with refractory epilepsy: results of an open-label multi-centre study. Eur J Paediatr Neurol. 2008;12(4): 321-327.

10. Pina-Garza JE, Nordli DR Jr, Rating D, et al. Adjunctive levetiracetam in infants and young children with refractory partial-onset seizures. Epilepsia. 2009;50(5):1141-1149.

11. Schiemann-Delgado J, Yang H, Loge Cde L, et al. A long-term open-label extension study assessing cognition and behavior, tolerability, safety, and efficacy of adjunctive levetiracetam in children aged 4 to 16 years with partial-onset seizures. J Child Neurol. 2012;27(1):80-89.

12. Lynch BA, Lambeng N, Nocka K, et al. The synaptic vesicle protein SV2A is the binding site for the antiepileptic drug levetiracetam. Proc Natl Acad Sci U S A. 2004;101(26):9861-9866.

13. Kaminski RM, Gillard M, Leclercq K, et al. Proepileptic phenotype of SV2A-deficient mice is associated with reduced anticonvulsant efficacy of levetiracetam. Epilepsia. 2009;50(7):1729-1740.

14. Crowder KM, Gunther JM, Jones TA, et al. Abnormal neurotransmission in mice lacking synaptic vesicle protein 2A (SV2A). Proc Natl Acad Sci U S A. 1999;96(26):15268-15273.

15. van Vliet EA, Aronica E, Redeker S, Boer K, Gorter JA. Decreased expression of synaptic vesicle protein $2 \mathrm{~A}$, the binding site for levetiracetam, during epileptogenesis and chronic epilepsy. Epilepsia. 2009;50(3):422-433.

16. Goraya JS, Khurana DS, Valencia I, et al. Intravenous levetiracetam in children with epilepsy. Pediatr Neurol. 2008;38(3):177-180.

17. Michaelides C, Thibert RL, Shapiro MJ, et al. Tolerability and dosing experience of intravenous levetiracetam in children and infants. Epilepsy Res. 2008;81(2-3):143-147.

18. Grosso S, Franzoni E, Coppola G, et al. Efficacy and safety of levetiracetam: an add-on trial in children with refractory epilepsy. Seizure. 2005;14(4):248-253.

19. Obeid M, Pong AW. Efficacy and tolerability of high oral doses of levetiracetam in children with epilepsy. Epilepsy Res. 2010;91(1): 101-105.

20. Giroux PC, Salas-Prato M, Theoret Y, Carmant L. Levetiracetam in children with refractory epilepsy: lack of correlation between plasma concentration and efficacy. Seizure. 2009;18(8):559-563.

21. Patsalos PN. Pharmacokinetic profile of levetiracetam: toward ideal characteristics. Pharmacol Ther. 2000;85(2):77-85.

22. Pellock JM, Glauser TA, Bebin EM, et al. Pharmacokinetic study of levetiracetam in children. Epilepsia. 2001;42(12):1574-1579.

23. Glauser TA, Mitchell WG, Weinstock A, et al. Pharmacokinetics of levetiracetam in infants and young children with epilepsy. Epilepsia. 2007;48(6):1117-1122.

24. Fountain NB, Conry JA, Rodriguez-Leyva I, et al. Prospective assessment of levetiracetam pharmacokinetics during dose escalation in 4- to 12-year-old children with partial-onset seizures on concomitant carbamazepine or valproate. Epilepsy Res. 2007;74(1):60-69.

25. Nicolas JM, Collart P, Gerin B, et al. In vitro evaluation of potential drug interactions with levetiracetam, a new antiepileptic agent. Drug Metab Dispos. 1999;27(2):250-254.

26. Hirsch LJ, Arif H, Buchsbaum R, et al. Effect of age and comedication on levetiracetam pharmacokinetics and tolerability. Epilepsia. 2007; 48(7):1351-1359.

27. Contin M, Albani F, Riva R, Baruzzi A. Levetiracetam therapeutic monitoring in patients with epilepsy: effect of concomitant antiepileptic drugs. Ther Drug Monit. 2004;26(4):375-379.

28. Dahlin MG, Wide K, Ohman I. Age and comedications influence levetiracetam pharmacokinetics in children. Pediatr Neurol. 2010;43(4): 231-235. 
29. Otoul C, De Smedt H, Stockis A. Lack of pharmacokinetic interaction of levetiracetam on carbamazepine, valproic acid, topiramate, and lamotrigine in children with epilepsy. Epilepsia. 2007;48(11): 2111-2115.

30. Levisohn PM, Mintz M, Hunter SJ, Yang H, Jones J. N01103 Levetiracetam Study Group. Neurocognitive effects of adjunctive levetiracetam in children with partial-onset seizures: A randomized, double-blind, placebo-controlled, noninferiority trial. Epilepsia. 2009; 50(11):2377-2389.

31. Pina-Garza JE, Schiemann-Delgado J, Yang H, Duncan B, Hadac J, Hunter SJ. Adjunctive levetiracetam in patients aged 1 month to $<4$ years with partial-onset seizures: subpopulation analysis of a prospective, open-label extension study of up to 48 weeks. Clin Ther. 2010;32(11):1935-1950.

32. de la Loge C, Hunter SJ, Schiemann J, Yang H. Assessment of behavioral and emotional functioning using standardized instruments in children and adolescents with partial-onset seizures treated with adjunctive levetiracetam in a randomized, placebo-controlled trial. Epilepsy Behav. 2010;18(3):291-298.

33. Mbizvo GK, Dixon P, Hutton JL, Marson AG. Levetiracetam add-on for drug-resistant focal epilepsy: an updated Cochrane Review. Cochrane Database Syst Rev. 2012;9:CD001901.

34. Glauser TA, Pellock JM, Bebin EM, et al. Efficacy and safety of levetiracetam in children with partial seizures: an open-label trial. Epilepsia. 2002;43(5):518-524.

35. Grosso S, Cordelli DM, Franzoni E, et al. Efficacy and safety of levetiracetam in infants and young children with refractory epilepsy. Seizure. 2007;16(4):345-350.

36. Chhun S, Troude P, Villeneuve N, et al. A prospective open-labeled trial with levetiracetam in pediatric epilepsy syndromes: continuous spikes and waves during sleep is definitely a target. Seizure. 2011;20(4): 320-325.

37. Tan MJ, Appleton RE. Efficacy and tolerability of levetiracetam in children aged 10 years and younger: a clinical experience. Seizure. 2004;13(3):142-145.

38. Wheless JW, Ng YT. Levetiracetam in refractory pediatric epilepsy. J Child Neurol. 2002;17(6):413-415.

39. French JA, Kanner AM, Bautista J, et al. Efficacy and tolerability of the new antiepileptic drugs II: treatment of refractory epilepsy: Report of the Therapeutics and Technology Assessment Subcommittee and Quality Standards Subcommittee of the American Academy of Neurology and the American Epilepsy Society. Neurology. 2004;62(8):1261-1273.

40. Verdru P. Epilepsy in children: the evidence for new antiepileptic drugs. Acta Neurol Scand Suppl. 2005;181:17-20.

41. Cilio MR, Bianchi R, Balestri M, et al. Intravenous levetiracetam terminates refractory status epilepticus in two patients with migrating partial seizures in infancy. Epilepsy Res. 2009;86(1):66-71.

42. Kirmani BF, Crisp ED, Kayani S, Rajab H. Role of intravenous levetiracetam in acute seizure management of children. Pediatr Neurol. 2009;41(1):37-39.

43. McTague A, Kneen R, Kumar R, Spinty S, Appleton R. Intravenous levetiracetam in acute repetitive seizures and status epilepticus in children: experience from a children's hospital. Seizure. 2012;21(7): 529-534.

44. Ben-Menachem E, Falter U. Efficacy and tolerability of levetiracetam $3000 \mathrm{mg} / \mathrm{d}$ in patients with refractory partial seizures: a multicenter, double-blind, responder-selected study evaluating monotherapy. European Levetiracetam Study Group. Epilepsia. 2000;41(10):1276-1283.

45. Alsaadi TM, Shatzel A, Marquez AV, Jorgensen J, Farias S. Clinical experience of levetiracetam monotherapy for adults with epilepsy: 1-year follow-up study. Seizure. 2005;14(2):139-142.

46. Khurana DS, Kothare SV, Valencia I, Melvin JJ, Legido A. Levetiracetam monotherapy in children with epilepsy. Pediatr Neurol. 2007;36(4):227-230

47. Glauser TA, Cnaan A, Shinnar S, et al. Ethosuximide, valproic acid, and lamotrigine in childhood absence epilepsy. $N$ Engl J Med. 2010; 362(9):790-799.
48. Duchowny M, Pellock JM, Graf WD, et al. A placebo-controlled trial of lamotrigine add-on therapy for partial seizures in children. Lamictal Pediatric Partial Seizure Study Group. Neurology. 1999;53(8): 1724-1731.

49. Camposano SE, Major P, Halpern E, Thiele EA. Vigabatrin in the treatment of childhood epilepsy: a retrospective chart review of efficacy and safety profile. Epilepsia. 2008;49(7):1186-1191.

50. Bouma PA, Bovenkerk AC, Westendorp RG, Brouwer OF. The course of benign partial epilepsy of childhood with centrotemporal spikes: a meta-analysis. Neurology. 1997;48(2):430-437.

51. Coppola G, Franzoni E, Verrotti A, et al. Levetiracetam or oxcarbazepine as monotherapy in newly diagnosed benign epilepsy of childhood with centrotemporal spikes (BECTS): an open-label, parallel group trial. Brain Dev. 2007;29(5):281-284.

52. Croona C, Kihlgren M, Lundberg S, Eeg-Olofsson O, Eeg-Olofsson KE. Neuropsychological findings in children with benign childhood epilepsy with centrotemporal spikes. Dev Med Child Neurol. 1999;41(12):813-818.

53. Giordani B, Caveney AF, Laughrin D, et al. Cognition and behavior in children with benign epilepsy with centrotemporal spikes (BECTS). Epilepsy Res. 2006;70(1):89-94.

54. Weglage J, Demsky A, Pietsch M, Kurlemann G. Neuropsychological, intellectual, and behavioral findings in patients with centrotemporal spikes with and without seizures. Dev Med Child Neurol. 1997;39(10): 646-651.

55. Chu-Shore CJ, Major P, Camposano S, Muzykewicz D, Thiele EA. The natural history of epilepsy in tuberous sclerosis complex. Epilepsia. 2010;51(7):1236-1241.

56. Collins JJ, Tudor C, Leonard JM, Chuck G, Franz DN. Levetiracetam as adjunctive antiepileptic therapy for patients with tuberous sclerosis complex: a retrospective open-label trial. J Child Neurol. 2006;21(1): 53-57.

57. Veggiotti P, Beccaria F, Guerrini R, Capovilla G, Lanzi G. Continuous spike-and-wave activity during slow-wave sleep: syndrome or EEG pattern? Epilepsia. 1999;40(11):1593-1601.

58. International League Against Epilepsy. Proposal for revised classification of epilepsies and epileptic syndromes. Commission on Classification and Terminology of the International League Against Epilepsy. Epilepsia. 1989;30(4):389-399.

59. Wang SB, Weng WC, Fan PC, Lee WT. Levetiracetam in continuous spike waves during slow-wave sleep syndrome. Pediatr Neurol. 2008; 39(2):85-90

60. Capovilla G, Beccaria F, Cagdas S, Montagnini A, Segala R, Paganelli D. Efficacy of levetiracetam in pharmacoresistant continuous spikes and waves during slow sleep. Acta Neurol Scand. 2004;110(3): 144-147.

61. Ramantani G, Ikonomidou C, Walter B, Rating D, Dinger J. Levetiracetam: safety and efficacy in neonatal seizures. Eur J Paediatr Neurol. 2011;15(1):1-7.

62. Furwentsches A, Bussmann C, Ramantani G, et al. Levetiracetam in the treatment of neonatal seizures: a pilot study. Seizure. 2010;19(3): $185-189$.

63. Khan O, Chang E, Cipriani C, Wright C, Crisp E, Kirmani B. Use of intravenous levetiracetam for management of acute seizures in neonates. Pediatr Neurol. 2011;44(4):265-269.

64. Abend NS, Gutierrez-Colina AM, Monk HM, Dlugos DJ, Clancy RR. Levetiracetam for treatment of neonatal seizures. J Child Neurol. 2011;26(4):465-470.

65. Bittigau P, Sifringer M, Ikonomidou C. Antiepileptic drugs and apoptosis in the developing brain. Ann NY Acad Sci. 2003;993:103-114.

66. Manthey D, Asimiadou S, Stefovska V, et al. Sulthiame but not levetiracetam exerts neurotoxic effect in the developing rat brain. Exp Neurol. 2005;193(2):497-503.

67. Kim J, Kondratyev A, Gale K. Antiepileptic drug-induced neuronal cell death in the immature brain: effects of carbamazepine, topiramate, and levetiracetam as monotherapy versus polytherapy. J Pharmacol Exp Ther. 2007;323(1):165-173. 
68. Forcelli PA, Janssen MJ, Vicini S, Gale K. Neonatal exposure to antiepileptic drugs disrupts striatal synaptic development. Ann Neurol. 2012;72(3):363-372.

69. Kossoff EH, Bergey GK, Freeman JM, Vining EP. Levetiracetam psychosis in children with epilepsy. Epilepsia. 2001;42(12): 1611-1613.

70. Youroukos S, Lazopoulou D, Michelakou D, Karagianni J. Acute psychosis associated with levetiracetam. Epileptic Disord. 2003;5(2): 117-119.

71. Tamarelle C, Pandit F, Mazarati A, Riquet A, Vallee L, Auvin S. Levetiracetam-induced depression in a 5-year-old child with partial epilepsy. Seizure. 2009;18(3):235-236.

72. Mula M, Kanner AM, Schmitz B, Schachter S. Antiepileptic drugs and suicidality: an expert consensus statement from the Task Force on Therapeutic strategies of the ILAE Commission on Neuropsychobiology. Epilepsia. September 20, 2012. [Epub ahead of print.]

73. Christensen J, Vestergaard M, Mortensen PB, Sidenius P, Agerbo E. Epilepsy and risk of suicide: a population-based case-control study. Lancet Neurol. 2007;6(8):693-698.
74. World Health Organization. Preventing Suicide: A Resource for Primary Health Care Workers. Geneva, Switzerland: World Health Organization; 2000.

75. Vaisleib II, Neft RA. Rapid dosage titration of levetiracetam in children. Pharmacotherapy. 2008;28(3):393-396.

76. Major P, Greenberg E, Khan A, Thiele EA. Pyridoxine supplementation for the treatment of levetiracetam-induced behavior side effects in children: preliminary results. Epilepsy Behav. 2008;13(3):557-559.

77. Dzhala VI, Talos DM, Sdrulla DA, et al. NKCC1 transporter facilitates seizures in the developing brain. Nat Med. 2005;11(11):1205-1213.

78. Kahle KT, Staley KJ. The bumetanide-sensitive Na-K-2Cl cotransporter NKCC1 as a potential target of a novel mechanism-based treatment strategy for neonatal seizures. Neurosurg Focus. 2008;25(3):E22.

79. US Food and Drug Administration. Drug Research and Children. 2011. Available from: http://www.fda.gov/Drugs/ResourcesForYou/ Consumers/ucm143565.htm. Accessed January 24, 2013.

\section{Publish your work in this journal}

Neuropsychiatric Disease and Treatment is an international, peerreviewed journal of clinical therapeutics and pharmacology focusing on concise rapid reporting of clinical or pre-clinical studies on a range of neuropsychiatric and neurological disorders. This journal is indexed on PubMed Central, the 'PsycINFO' database and CAS.
The manuscript management system is completely online and includes a very quick and fair peer-review system, which is all easy to use. Visit http://www.dovepress.com/testimonials.php to read real quotes from published authors.

Submit your manuscript here: http://www.dovepress.com/neuropsychiatric-disease-and-treatment-journal 